Journal of Marine Science and Technology; Vol. 15, No. 2; 2015: 105-118

DOI: $10.15625 / 1859-3097 / 15 / 2 / 6499$

http://www.vjs.ac.vn/index.php/jmst

\title{
PRESENT DAY DEFORMATION IN THE EAST VIETNAM SEA AND SURROUNDING REGIONS
}

\author{
Phan Trong Trinh*, Ngo Van Liem, Tran Dinh To, Nguyen Van Huong, Vy Quoc Hai, \\ Bui Van Thom, Tran Van Phong, Hoang Quang Vinh, Nguyen Quang Xuyen, \\ Nguyen Viet Thuan, Nguyen Dang Tuc, Dinh Van Thuan, Nguyen Trong Tan, \\ Bui Thi Thao, Nguyen Viet Tien, Le Minh Tung, Tran Quoc Hung \\ Institute of Geological Sciences-VAST \\ EE-mail: phantrongt@yahoo.com \\ Received: 15-10-2014
}

\begin{abstract}
This paper presents velocities of present-day tectonic movement and strain rate in the East Vietnam Sea (South China Sea) and surroundings determined from GPS campaigns between 2007 and 2010. We determine absolute velocities of GPS stations in the ITRF05 frame. The result indicates that GPS stations in the North of East Vietnam Sea move eastwards with the slip rate of $30-39 \mathrm{~mm} / \mathrm{yr}$, southwards at the velocities of $8-11 \mathrm{~mm} / \mathrm{yr}$. Song Tu Tay offshore moves eastwards at the rate of $\sim 24 \mathrm{~mm} / \mathrm{yr}$ and southwards at $\sim 9 \mathrm{~mm} / \mathrm{yr}$. GPS stations in the South of East Vietnam Sea move to the east at the rate of $\sim 22 \mathrm{~mm} / \mathrm{yr}$ and to the south at the velocities of 7 $11 \mathrm{~mm} / \mathrm{yr}$. The effect of relative movement shows that the Western Margin Fault Zone activates as left lateral fault zone at the slip rate less than $4 \mathrm{~mm} / y e a r$. In Western plateau, the first result from 2012 - 2013 GPS measurement shows that the velocities to the east vary from $21.5 \mathrm{~mm} / \mathrm{yr}$ to $24.7 \mathrm{~mm} /$ year. The velocities to the south vary from $10.5 \mathrm{~mm} / \mathrm{yr}$ to $14.6 \mathrm{~mm} /$ year. GPS solutions determined from our campaigns are combined with data from various authors and international projects to determine the strain rate in the East Vietnam Sea. Principal strain rate changes from 15 nanostrain/yr to 9 nanostrain/yr in the East Vietnam Sea. Principal strain rate and maximum shear strain rate along the Red River Fault Zone are in order of 10 nanostrain/year. East Vietnam Sea is considered to belong to the Sunda block.
\end{abstract}

Keywords: Present-day movement, tectonic gradient, velocity, subduction zone, extension, principal strain rate, maximum slip rate, Western plateau.

\section{INTRODUCTION}

The East Vietnam Sea has been regarded as a marginal sea in the West Pacific Rim. The eastern margin of the East Vietnam Sea is rather complex with an occurrence of two subduction zones dipping in two opposite directions: a subduction zone along the Manila trench dipping to the east and another zone along the eastern margin of the Philippines dipping to the west. Over the past 3 decades, various models have been proposed that explain this deformation either by viscous flow of a continuously deforming medium [1] or by motion of rigid lithosphere blocks along narrow fault zones [2]. A well-defined East Vietnam Sea region's motion allows for better assessment and further improvement of these models. The result of the project "Geodynamics of South and Southeast Asia" (GEODYSSEA) confirmed Sunda as a coherent block which moves with respect to Eurasia and is separated 
from the Siberian platform through a series of deforming and moving blocks [3]. Since 1998 the GPS network in SE Asia has been significantly expanded with both campaign sites and continuously operated stations in the project "Southeast Asia: Mastering Environmental Research with Geodetic Space Techniques" (SEAMERGES). The Sunda block covers a part of Southeast Asian countries like Vietnam, Laos, Cambodia, Thailand, Malaysia, Brunei and Indonesia. It is bounded by active subduction zones like Philippine, Australian, and Indian submerged plates represented by large earthquakes and the majority of seismicity. Sundaland bock is bounded to the north by the southeasterly part of the IndiaEurasia collision zone and the South China block.Sunda interior is represented by a real low and shallow seismicity. This suggests Sundaland block moves as a rigid lithosphere block, although its tectonic origin is not monolithic [4]. Recent study of Simons et al.[2] indicated that Sundaland moves eastward at a velocity of $6 \pm 1 \mathrm{~mm} / \mathrm{yr}$ to $10 \pm 1 \mathrm{~mm} / \mathrm{yr}$ from south to north, respectively. Previous studies demonstrated that there is no difference in present day movement between Sundaland and South China blocks $[3,5]$ Sundaland is shown to move independently with respect to South China, the eastern part of Java, the island of Sulawesi, and the northern tip of Borneo. To the northeast, the southeastern part of the Red River fault [6-8] makes a geological boundary between the Sundaland and South China blocks (figure 1). Today it corresponds to a great right-lateral fault, following for over $900 \mathrm{~km}$ of the edges of four narrow high-grade gneiss ranges that together form the Ailao Shan-Red River metamorphic belt: the Con Voi mountain range in Vietnam, and the Ailao, Diancang and Xuelong Shan in Yunnan. The deformation along the Red River fault is smaller than 5 $\mathrm{mm} / \mathrm{yr}$ slip estimated from neotectonic studies [6, 9-11]. The strain field is compatible with right lateral displacement, but deformation across this fault zone shows small at the present time (Feigl et al., 2003). The Red River fault ends in the Red River Basin, characterized by a small and decreasing strain rate in the East Vietnam Sea [2]. The Red River basin was considered as a diffuse boundary zone between Sundaland and East Vietnam Sea, where the Red River fault no longer has a clear surface expression. The deformation to the southwest of the Red River fault is accommodated by multiple NE-SW strike-slip faults [12].

The great 2004 Sumatra earthquake was in the case which was related to convergent process along the Sunda subduction zone between the Indian-Australian plate and the Eurasian plate. For the assessment of tsunamis in Vietnam, we have to study not only Manila subduction zone, but also local sources of tsunami such as NW Borneo subduction zone and fault system at the margin of the East Vietnam Sea. These fracture zones are marked by some workers $[2,8,13]$. We have to answer 2 questions related to the existence of an active subduction zone at NW Borneo and how fast movement of active Western Margin Fault Zone (WMFZ). WMFZ is located at the westerly border of the East Vietnam Sea (figure 1). This fault zone has a long story in the evolution of the East Vietnam Sea. Some workers suggested that WMFZ is a large active fault zone that is a main source of earthquake and tsunami in East Vietnam Sea [8].

In this study, we give a novel solution to present-day tectonic movement in Vietnam Sea and adjacent field on the footing of our data from 2007 - 2010 GPS campaigns in the East Vietnam Sea and a combination of GPS solutions from previous works such as "Permanent Committee on GIS Infrastructure for Asia and the Pacific" (PCGIAP), "Asia Pacific Regional Geodetic Project” (APRGP), "Crustal Movement Observation Network of China" (CMONOC).

In order to clarify deformation in the East Vietnam Sea, we combined various GPS solutions to determine the strain rate on East Vietnam Sea. Our attention is paid to the WMFZ and subduction zone at NW Borneo, which are known as the highest seismogenic potential faults in the East Vietnam Sea. 
Present day deformation in the East Vietnam ...

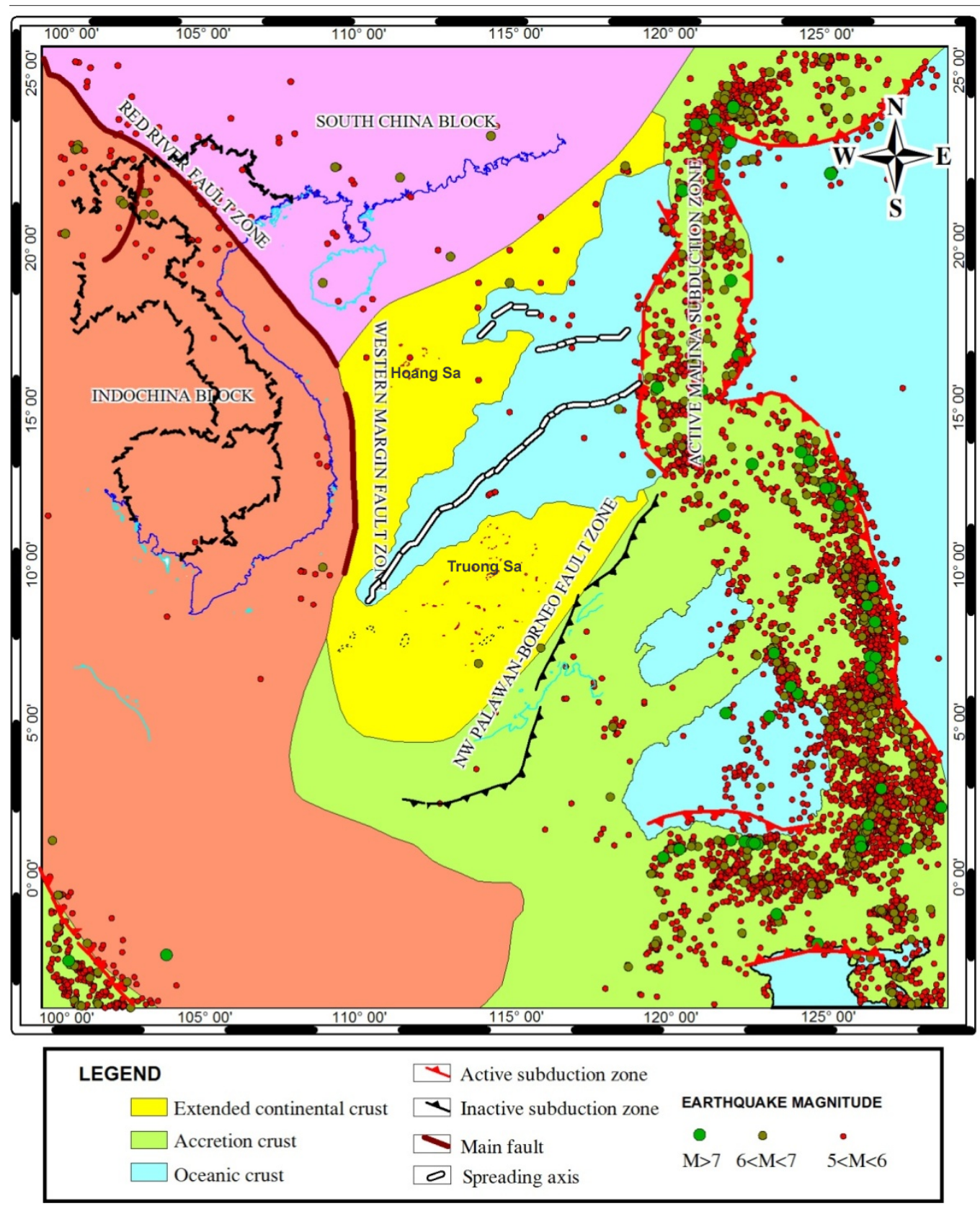

Fig. 1. Schematic tectonic map of East Vietnam Sea and surroundings

\section{MATERIALS AND METHODS}

We had carried out 4 GPS campaigns at stations LANG, BLV1, STT1, CDA1, DOHO, HUES and HOCM over the years 2007, 2008, 2009 and 2010. We used TRIMBLE SSI receivers COMPACT L1/L2 with ground plane antennas to record GPS signals. All the surveyswere observed at least in 1 weak during each session. GPS data sampling rate of 30 secondswas set to obtain more precise upward component. In each campaign, 7-day data were acquired and logging time for each day was 23 hours and 40 minutes. Database in this work, apart from GPS stations: LANG, BLV1, STT1, CDA1, HUES, DOHO and HOCM. Using 
international reference frame ITRF05, with known velocities of IGS stations: OCO, PIMO, BAKO, KUNM and WUHN, we estimated absolute velocities of each GPS station. The GPS data were firstly calculated independently in daily batches by GAMIT [14] and BERNESE 5.0 with a cutoff elevation angle of 10 degrees. Each point position was based on the ionosphere free combination of the zerodifference GPS observable at 5 minute intervals. Troposphere delays and gradients were stochastically estimated at each interval. Ocean loading effects were modeled. The individual point positions were merged into daily full-network solutions. The daily ambiguity-fixed solutions were combined with multiday averaged solutions using a sevenparameter Helmert transformation, in order to condense the results and to facilitate the detection and down-weighting of outliers. In each campaign, daily solutions were averaged over the campaign length, which varied from 7 to 12 days. The overall repeatability statistics of each combination solution were used to determine the formal errors in their covariance matrices. Formal errors were typically underestimated in GPS processing results. Assigning realistic error estimates to the coordinates should result in more realistic velocity uncertainty estimates. In general, the daily coordinaterepeatswere $2-3 \mathrm{~mm}$ in the north and east horizontal positions, respectively, and $8-9 \mathrm{~mm}$ for the height (figure 2). The campaign fiducially-free network solutions were transformed into the IGS05 using the coordinates and velocities of well determined global IGS stations to estimate seven-parameter Helmert transformations. The remaining IGS sites, including NTUS, BAKO, and PIMO in SE Asia, were adjusted along with the local network.
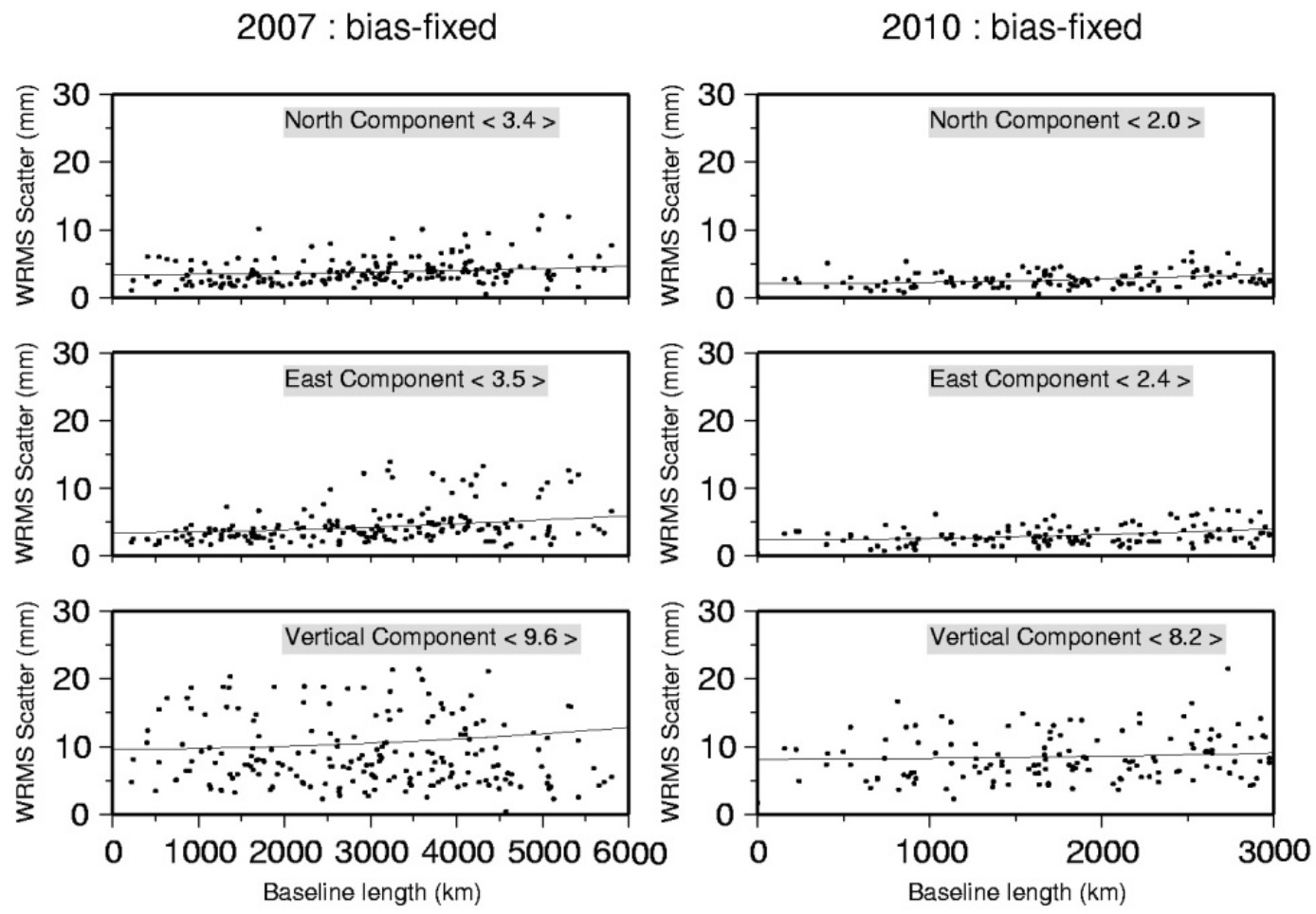

Fig. 2. GAMIT's standard errors of daily bias-fixed solution in the relation with baseline lengths

Strain rate for each triangle was calculated by using QOCA software [15]. The principle of calculation of strain rate and error was represented by $[15,16]$. Normal and shear 
strains were firstly calculated for each triangle and transferred to the principal strain rate and the direction of principal strain rates. Maximum shear train rate and rotation rate for each triangle are also calculated.

\section{RESULTS}

Absolute velocities processed from two softwares GAMIT and BERNESE are represented in figure 3 and table 1 . The result indicates that the Lang station (LANG) moves eastward at slip rate of $\sim 39 \mathrm{~mm} / \mathrm{yr}$, southward at slip rate of $\sim 11 \mathrm{~mm} / \mathrm{yr}$. The rate of Bach Long Vi (BLV1) is $\sim 30 \mathrm{~mm} / \mathrm{yr}$ for the eastern component and $\sim 11 \mathrm{~mm} / \mathrm{yr}$ for southern component. Song Tu Tay (STT1) moves eastwards at the rate of $\sim 24 \mathrm{~mm} / \mathrm{yr}$ and southwards at $8 \mathrm{~mm} / \mathrm{yr}$. Con Dao (CDA1) moves to the east at the rate of $\sim 22 \mathrm{~mm} / \mathrm{yr}$ and to the south at the rate of $\sim 6 \mathrm{~mm} / \mathrm{yr}$. Dong Hoi (DOHO) moves to the east at the rate of $\sim 27$ $\mathrm{mm} / \mathrm{yr}$ and to the south at the rate of $\sim 8 \mathrm{~mm} / \mathrm{yr}$. Hue (HUES) moves to the east at the rate of $\sim 30 \mathrm{~mm} / \mathrm{yr}$ and to the south at the rate of $\sim 12$ $\mathrm{mm} / \mathrm{yr}$. The HOCM moves to the east at the rate of $\sim 22 \mathrm{~mm} / \mathrm{yr}$ and to the south at the rate of $\sim 10 \mathrm{~mm} / \mathrm{yr}$. Calculated errors in both directions vary from 0.6 to $1.5 \mathrm{~mm} / \mathrm{yr}$. The result shows that velocities determined from GAMIT and Bernese at HUES and CDA1 are rather different. In Western plateau, the first result from 2012 - 2013 GPS measurement shows that the velocities to the east vary from $21.5 \mathrm{~mm} / \mathrm{yr}$ (station DPO0) to $24.7 \mathrm{~mm} / \mathrm{yr}$ (station NHAT). The velocities to the south vary from $10.5 \mathrm{~mm} / \mathrm{yr}$ (station PQUY) to $14.64 \mathrm{~mm} / \mathrm{yr}$ (station DATO).

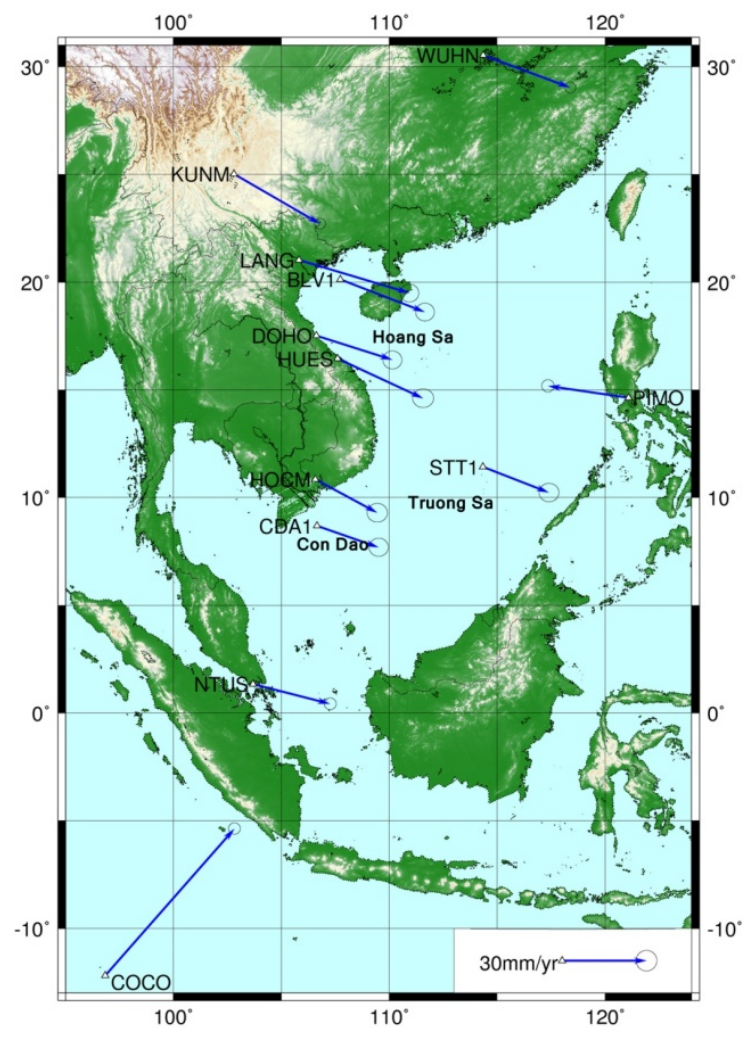

Fig. 3. Absolute velocities in ITRF05 of GPS sites in Vietnam based on data from four campaigns over the years 2007, 2008, 2009 and 2010; Error ellipses are 95\% confidence limits

Table 1. Velocities in ITRF05 and error in East Vietnam Sea calculated by GAMIT and BERNESE

\begin{tabular}{|c|c|c|c|c|c|c|c|c|}
\hline Station & 4 Char Code & Longitude & Latitude & Software & $V_{n}{ }^{a}$ & $V_{e}^{a}$ & $1 \sigma_{n}^{a}$ & $1 \sigma_{\mathrm{e}}^{a}$ \\
\hline \multirow{2}{*}{ Bach Long Vi island } & \multirow{2}{*}{ BLV1 } & \multirow{2}{*}{107,723} & \multirow{2}{*}{20,128} & GAMIT & 30.1 & -12.5 & 1.3 & 1.36 \\
\hline & & & & BERNESE & 30.1 & -10.8 & 0.1 & 0.10 \\
\hline \multirow{2}{*}{ Hanoi } & \multirow{2}{*}{ LANG } & \multirow{2}{*}{105,805} & \multirow{2}{*}{21,025} & GAMIT & 39.3 & -12.7 & 1.3 & 1.34 \\
\hline & & & & BERNESE & 39.3 & -10.8 & 0.1 & 0.10 \\
\hline \multirow{2}{*}{ Dong Hoi } & \multirow{2}{*}{$\mathrm{DOHO}$} & \multirow{2}{*}{106,616} & \multirow{2}{*}{17,507} & GAMIT & 26.6 & -9.5 & 1.3 & 1.4 \\
\hline & & & & BERNESE & 27.4 & -7.7 & 0.1 & 0.1 \\
\hline \multirow{2}{*}{ Hue } & \multirow{2}{*}{ HUES } & \multirow{2}{*}{107,593} & \multirow{2}{*}{16,459} & GAMIT & 31.2 & -16.5 & 1.4 & 1.5 \\
\hline & & & & BERNESE & 29.7 & -11.8 & 0.1 & 0.1 \\
\hline \multirow{2}{*}{ Song Tu Tay island } & \multirow{2}{*}{ STT1 } & \multirow{2}{*}{114,331} & \multirow{2}{*}{11,429} & GAMIT & 23.4 & -10.6 & 1.3 & 1.4 \\
\hline & & & & BERNESE & 23.6 & -7.8 & 0.1 & 0.2 \\
\hline \multirow{2}{*}{ Con Dao island } & \multirow{2}{*}{ CDA1 } & \multirow{2}{*}{106,652} & \multirow{2}{*}{8,692} & GAMIT & 21.8 & -9.8 & 1.3 & 1.4 \\
\hline & & & & BERNESE & 22.0 & -5.5 & 0.1 & 0.1 \\
\hline \multirow{2}{*}{ Ho Chi Minh } & \multirow{2}{*}{ HOCM } & \multirow{2}{*}{106,560} & \multirow{2}{*}{10,849} & GAMIT & 22.0 & -13.8 & 1.4 & 1.5 \\
\hline & & & & BERNESE & 22.2 & -10.1 & 0.1 & 0.1 \\
\hline
\end{tabular}


Phan Trong Trinh, Ngo Van Liem, ...

The relative slip rate of $\mathrm{LANG}$, BLV1,

DOHO, CDA1 and HOCM move to the north DOHO, HUES, CDA1, HOCM were determined by fixing STT1. The result is represented in table 2 . In comparison to STT1, at the rate from $1.0 \pm 1.8 \mathrm{~mm} / \mathrm{yr}$ to $6.3 \pm 1.9$ $\mathrm{mm} / \mathrm{yr}$, to the west at the rate from $0.0 \pm 1.8$ $\mathrm{mm} / \mathrm{yr}$ to $0.7 \pm 1.8 \mathrm{~mm} / \mathrm{yr}$.

Table 2. Relative velocities in comparison to those of Song Tu Tay island in ITRF05

\begin{tabular}{|c|c|c|c|c|c|c|c|c|}
\hline Station & Char Code & Longitude & Latitude & Software & $V_{e}{ }^{a}$ & $V_{n}{ }^{a}$ & $1 \sigma_{\mathrm{e}}^{\mathrm{a}}$ & $1 \sigma_{n}^{a}$ \\
\hline \multirow{2}{*}{ Bach Long Vi island } & \multirow{2}{*}{ BLV1 } & \multirow{2}{*}{107,723} & \multirow{2}{*}{20,128} & GAMIT & 9.9 & -3.9 & 1.9 & 1.8 \\
\hline & & & & BERNESE & 9.3 & -4.6 & 0.5 & 0.2 \\
\hline \multirow{2}{*}{ Hanoi } & \multirow{2}{*}{ LANG } & \multirow{2}{*}{105,805} & \multirow{2}{*}{21,025} & GAMIT & 19.4 & -4.5 & 1.9 & 1.8 \\
\hline & & & & BERNESE & 20.1 & -4.6 & 0.5 & 0.2 \\
\hline \multirow{2}{*}{ Dong Hoi } & \multirow{2}{*}{$\mathrm{DOHO}$} & \multirow{2}{*}{106,616} & \multirow{2}{*}{17,507} & GAMIT & 6.3 & -0.7 & 1.9 & 1.8 \\
\hline & & & & BERNESE & 7.9 & -0.9 & 0.5 & 0.2 \\
\hline \multirow{2}{*}{ Hue } & \multirow{2}{*}{ HUES } & \multirow{2}{*}{107.593} & \multirow{2}{*}{16.459} & GAMIT & 10.95 & -7.6 & 2.0 & 1.8 \\
\hline & & & & BERNESE & 8.4 & -5.1 & 0.4 & 0.2 \\
\hline \multirow{2}{*}{ Song Tu Tay island } & \multirow{2}{*}{ STT1 } & \multirow{2}{*}{114,331} & \multirow{2}{*}{11,429} & GAMIT & 0.0 & 0.0 & 0.0 & 0.0 \\
\hline & & & & BERNESE & 0.0 & 0.0 & 0.0 & 0.0 \\
\hline \multirow{2}{*}{ Con Dao island } & \multirow{2}{*}{ CDA1 } & \multirow{2}{*}{106,652} & \multirow{2}{*}{8,692} & GAMIT & 1.0 & 0.0 & 1.8 & 1.8 \\
\hline & & & & BERNESE & 0.7 & 1.2 & 0.5 & 0.2 \\
\hline \multirow{2}{*}{ Ho Chi Minh city } & \multirow{2}{*}{ HOCM } & \multirow{2}{*}{106,560} & \multirow{2}{*}{10,849} & GAMIT & 1.3 & -4.2 & 1.9 & 1.8 \\
\hline & & & & BERNESE & 1.9 & -3.5 & 0.6 & 0.2 \\
\hline
\end{tabular}

${ }^{a}$ Units are $\mathrm{mm} / \mathrm{yr}$

Table 3. Absolute velocities in Western plateau from 2012 - 2013 GPS measurements

\begin{tabular}{|c|c|c|c|c|c|c|}
\hline Name & Lon & Lat & Ve & $\mathrm{Vn}$ & $\mathrm{Se}$ & Sn \\
\hline BALO & 107.80 & 11.55 & 23.6 & -5.2 & 1.5 & 1.2 \\
\hline CAD1 & 109.01 & 11.60 & 23.9 & -7.1 & 0.9 & 0.9 \\
\hline CPRO & 107.82 & 13.83 & 22.4 & -5 & 1.2 & 0.9 \\
\hline CUJU & 107.92 & 12.61 & 25.2 & -8.2 & 1.2 & 0.9 \\
\hline DALA & 108.44 & 11.95 & 23.2 & -4.4 & 1.2 & 0.9 \\
\hline DATO & 107.84 & 14.64 & 23.5 & -5.6 & 1.2 & 0.9 \\
\hline DOAO & 108.23 & 14.07 & 22.6 & -8.9 & 1.2 & 0.9 \\
\hline DPO0 & 108.60 & 13.91 & 21.5 & -8.2 & 1.2 & 0.9 \\
\hline GIAN & 107.67 & 12.00 & 21.7 & -1.1 & 1.2 & 1.2 \\
\hline HLEO & 108.20 & 13.21 & 27.9 & -6.8 & 1.2 & 0.9 \\
\hline NHAT & 109.21 & 12.20 & 24.7 & -8.4 & 1.2 & 0.9 \\
\hline PQUY & 108.93 & 10.51 & 25.3 & -7.4 & 1.2 & 1.2 \\
\hline QUYN & 109.22 & 13.76 & 23 & -7.5 & 1.2 & 0.9 \\
\hline TUYP & 108.71 & 11.18 & 22.5 & -7.2 & 1.2 & 0.9 \\
\hline
\end{tabular}

To calculate the strain rate of the East Vietnam Sea, we combine our GAMIT solution with velocities of YONG, JB21, XIAM from $\mathrm{Hu}$ et al. (2007), TNSM from Yu et al. [17], KUCH, MIRI, LINA from PCGIAP \& APRGP
[18], PUER from Simons et al. [2]. The solution from Bernese is not used in this calculation as the error is too small in comparison to the error of GAMIT. We will discuss later. Velocities from $[2,18]$ were transferred from ITRF2000 to IGS05 reference by using QOCA software. The results of strain rate calculated by QOCA are represented in table 4 and figure 4 . The errors of principal strain rate at the triangles $\mathrm{T} 14$ and $\mathrm{T} 15$ are only 0.2-0.3nano-strain/yr thanks to the high precision of continuous GPS sites YONG, JB21, XIAM. Extensive principal strain rate ranges from -1.7 nanostrain/yr \pm 0.2 nanostrain/yr to 19 nanostrain/yr \pm 3.3nanostrain/yr. The compressive principal strain rate varies from -15 nanostrain/yr \pm 6.4 nanostrain/yr to -2.1 nanostrain/yr \pm 1.7 nanostrain/yr. Maximum shear strain rate is from 1.0 nanostrain/yr \pm 0.2 nanostrain/yr to 10.2 nanostrain/yr \pm 3.9 nanostrain/yr. The field of strain rate of continental shelf of the East Vietnam Sea demonstrates that presentday deformation is in transitional regime. 
Table 4. Strain rate calculated by the combination of GPS solution from PCGIAP, Hu et al., Simons et al. and this study [2, 18, 19]

\begin{tabular}{|c|c|c|c|c|c|c|c|c|c|c|}
\hline $\mathbf{N}$ & LON & LAT & $S R 1^{a}$ & $\sigma R 1^{a}$ & $\mathrm{SR2}^{\mathrm{a}}$ & $\sigma R 2^{\mathrm{a}}$ & $D 2^{b}$ & $\sigma D 2^{b}$ & SSR $^{a}$ & $\sigma \mathrm{SR}^{\mathrm{a}}$ \\
\hline $\mathrm{T} 1$ & 105,750 & 20,902 & 9.3 & 7.2 & -11.0 & 2.8 & -12 & 11 & 10.2 & 3.9 \\
\hline T2 & 106,950 & 23,480 & 5.4 & 1.3 & -6.7 & 2.3 & -26 & 6 & 6.1 & 1.3 \\
\hline T3 & 110,133 & 20,725 & 3.6 & 3.4 & -2.7 & 0.4 & -20 & 16 & 3.2 & 1.8 \\
\hline T4 & 113,147 & 20,930 & -1.7 & 0.2 & -3.7 & 0.3 & 120 & 5 & 1.0 & 0.2 \\
\hline T5 & 115,062 & 23,483 & 0.7 & 0.3 & -4.4 & 0.3 & -30 & 2 & 2.6 & 0.3 \\
\hline T6 & 108,902 & 18,172 & 7.2 & 3.4 & -8.8 & 5.1 & -9 & 11 & 8.0 & 3.1 \\
\hline T7 & 111,125 & 15,279 & 9.6 & 2.8 & -5.2 & 2.1 & -22 & 7 & 7.4 & 1.8 \\
\hline T8 & 114,446 & 16,330 & -0.4 & 0.9 & -10.0 & 2.3 & 114 & 7 & 4.8 & 1.3 \\
\hline T9 & 109,187 & 13,613 & 6.9 & 4.5 & -3.5 & 2.7 & 105 & 14 & 5.2 & 2.6 \\
\hline T10 & 108,516 & 10,716 & 1.8 & 2.2 & -15.0 & 6.4 & -20 & 12 & 8.4 & 3.4 \\
\hline T11 & 106,843 & 3,892 & 0.8 & 2.5 & -6.9 & 2.0 & 48 & 13 & 3.9 & 1.5 \\
\hline T12 & 110,293 & 4,908 & 1.0 & 1.6 & -2.7 & 3.0 & 37 & 23 & 1.9 & 1.8 \\
\hline T13 & 111,660 & 8,180 & 2.0 & 2.0 & -2.1 & 1.7 & 1 & 19 & 2.1 & 1.3 \\
\hline T14 & 116,409 & 9,145 & 19.0 & 3.3 & -3.6 & 1.9 & 2 & 5 & 11.3 & 1.9 \\
\hline T15 & 114,793 & 7,236 & 0.6 & 4.3 & -2.4 & 1.6 & 20 & 39 & 1.5 & 2.2 \\
\hline
\end{tabular}

SR1, SR2, SSR are extensive principal strain rate, compressive principal strain rate and maximum shear strain rate, respectively. D2 is the direction of compressive principal strain rate; $\sigma R 1^{a}, \sigma R 2^{a}$, $\sigma S 1^{a}, \sigma D 2^{b}$ are errors of extensive principal strain rate, compressive principal strain rate, maximum shear strain rate and direction of compressive principal strain rate, respectively, a) Unit is nano-strain/yr; $b$ ) Unit is degree

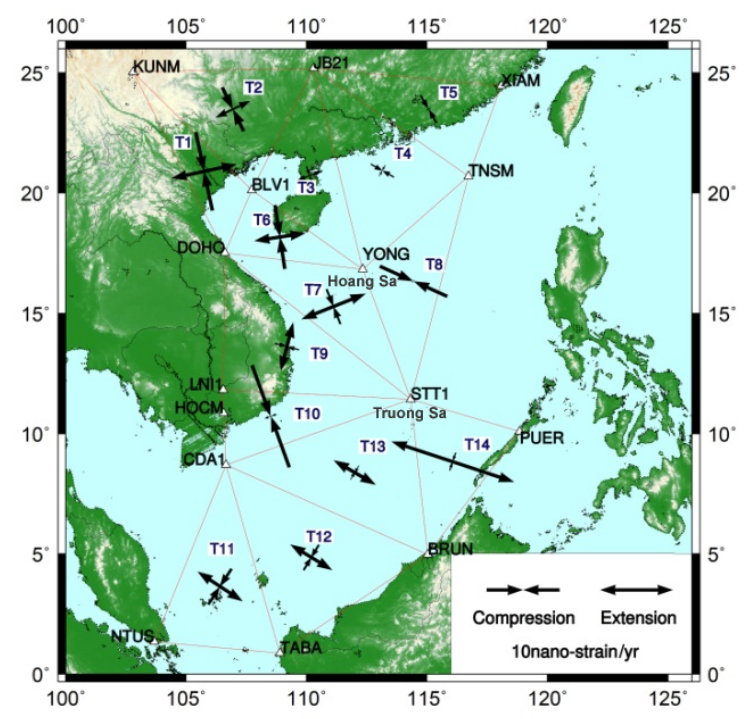

Fig. 4. Distribution of maximum and minimum strain rates in East Vietnam

Sea; The transitional state of strain is consistent with transitional state of stress; Strain rate calculated by the combination of GPS solution from PCGIAP, Simons et al. and this study $[2,18]$

\section{DISCUSSION}

All GPS stations are currently moving eastsoutheastward as in Vietnam mainland. This result is consistent with moving direction of Hainan, Guangxi, Guangdong as well as all Southeast China margins. This implies that deformation of the East Vietnam Sea is mainly controlled by collision between the IndianAustralian plate and the Eurasian plate (figure 5). Le Huy Minh et al. [10] based on continous GPS from 2005 - 2013 to determine the velocities at Phu Thuy (PHUT), Hue (HUES) and Ho Chi Minh (HOCM)stations. The PHUT is located $30 \mathrm{~km}$ far from LANG. In HOCM, our two methods define latitudical rate of $22 \mathrm{~mm} /$ year, consistent with the value of $23 \mathrm{~mm} / \mathrm{yr}$ determined by Le Huy Minh et al., (approximately 1 times the error). The values of longitudinal velocity defined by the two methods are $13.8 \mathrm{~mm} / \mathrm{yr}$ and $10.1 \mathrm{~mm} / \mathrm{yr}$, respectively. The average value of both methods is as close to the value $-11 \mathrm{~mm} / \mathrm{yr}$ determined by Le Huy Minh et al. So we assert as the data is not yet big enough, using two methods simultaneously will contribute to improving the reliability of research result.In HUES, two methods determine the longitudinal 
velocities of $31.2 \mathrm{~mm} / \mathrm{yr}$ and $29.7 \mathrm{~mm} / \mathrm{yr}$ with an average value of $30.4 \mathrm{~mm} / \mathrm{yr}$. This value is quite compatible with the rate of $28.3 \mathrm{~mm} / \mathrm{yr}$ determined by Le Huy Minh et al. The longitudinal velocities determined by two methods are $-16.5 \mathrm{~mm} / \mathrm{yr}$ and $-11.8 \mathrm{~mm} / \mathrm{yr}$, with an average of -14.2 . Second value -11.8 $\mathrm{mm} / \mathrm{yr}$ determined by BERNESE method is also compatible with the velocity obtained by Le Huy Minh et al. (-13.6 mm/yr). The eastern velocity in Lang is too high in comparision with the result Le Huy Minh et al. [20, 21], since the Lang is located in the new building constructed in 2004. Irregular subsidence of the building causes the tilt of building and the formation of cracks of NS direction.

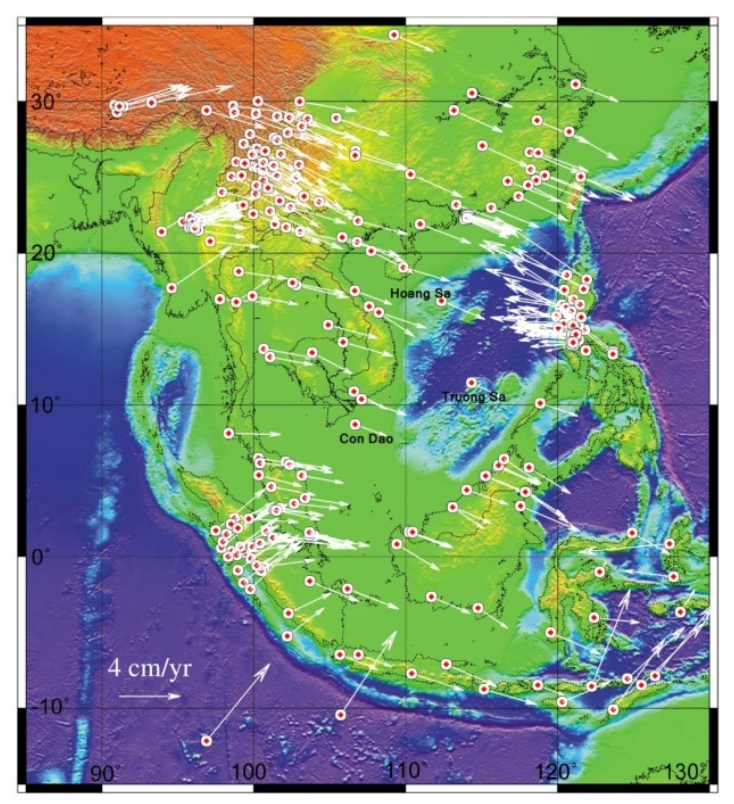

Fig. 5. Synthetic map of present day tectonic velocity combined from solutions of different regional and local GPS networks in Southeast

Asia including GEODYSSEA, PCGIAP, SEAMERGES and CMONOC projects and recent works [2, 3, 5,12, 22-28] and this work

The north of the East Vietnam Sea is now being closed at the rate of $77 \mathrm{~mm} / \mathrm{yr}$ with shortening axis striking WNW-ESE. Displacement vector orientations at LANG, BLV1, Hainan, Hoang Sa stations are almost opposite to displacement vectors at PIMO that depicts east-southeastward movement of the North East Vietnam Sea block subducting beneath Philippine Sea plate along the Manila trench. The East Vietnam Sea closing along the Manila subduction zone occurs at different rates, northwestward motion has the fastest rate at North Luzon and the rate decreases southeastward. The stations to the south (STT1, CDA1) are now moving southeastward which implies that geodynamic regime in the south of the East Vietnam Sea differs that in from the north of the East Vietnam Sea; and horizontal velocities are also smaller than those velocities at the north. The East Vietnam Sea is not being closed at the south (figure 5). In comparison with displacement vectors at Thailand, Vung Tau, Malaysia and Palawan, it can be seen that GPS displacement vectors at Con Dao and Song Tu Tay are smaller and somewhat southeastward oblique. In general, the south and southwest of the East Vietnam Sea are rarely deformed. With measured results at Con Dao, Ho Chi Minh city and Song Tu Tay, in comparison with the result at Palawan (GEODYSSEA and PCGIAP projects) it is shown that no compression is recorded at the North Borneo.

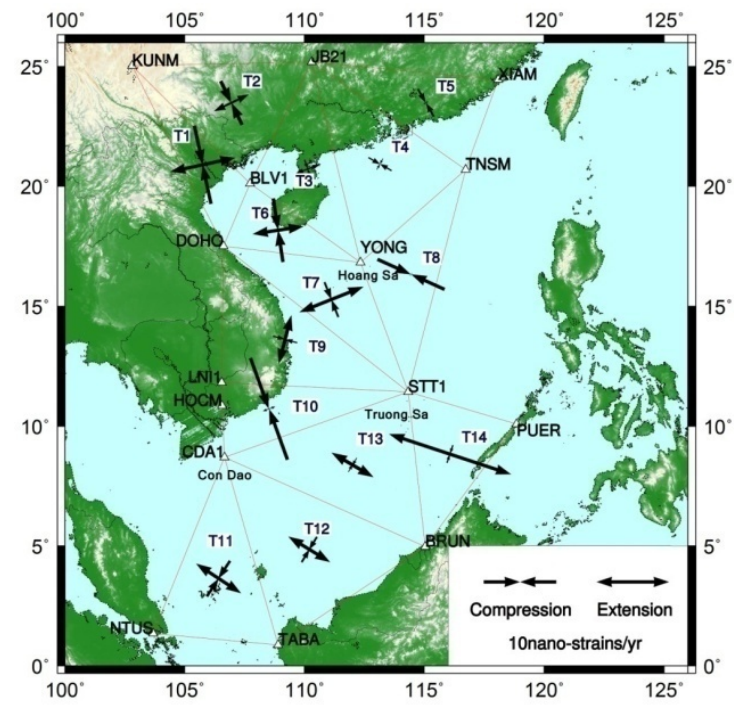

Fig. 6. Strain rate in East Vietnam Sea calculated by the combination of GPS data measured in North Borneo before 2004 Sumatra earthquake from Simons et al., Dawson et al. and this study [2, 25] 


\section{Present day deformation in the East Vietnam ...}

The result shows that the standard errors obtained from Bernese are much smaller than those derived from GAMIT. The effect of incomplete stochastic model, mainly due to neglecting the physical correlations in the observed time series, can be seen in the software-generated variance covariance matrix. A number of the GPS processing softwares consider the variance-covariance matrix of the observations without correlation, or simply deal with the diagonal components only. As a result, the quality assessment of the estimation could be too optimistic. The optimistic variance covariance matrix for GAMIT and Bernese GPS softwares was reported by Kashani et al. [29]. The variance-covariance matrix derived from GPS processing software underestimates the magnitude of the error, mainly due to the fact that physical correlations are normally neglected [29]. Formal accuracies derived from both softwares need to be scaled by applying a scaling factor that multiplies the softwarederived formal errors. In order to test the reliability and the validity of the variancecovariance matrix in both softwares, Kashani et al. [24] indicated that the overall scaling factor for GAMIT is over 10 times less than that for Bernese. The scaling factor for GAMIT in our case is also over 10 timesless than that for Bernese.

The result shows that the calculated velocities between GAMIT and Bernese are rather different for some stations such as HUES and CDA1. The cause of the difference of velocities determined by two softwares in CDA1 is not so clear. However, CDA1 is blocked by a crest of the mountain with the angle larger than 20 to the north. Simons et al. [12] assumed that the Sunda block is fixed, displacement estimation of some stations at NW Borneo indicated that there is a NW-SE compressive component. From this, they argued that there is a compressive boundary of the Sunda block running along the tip of northern Borneo. With measured results at Con Dao, Ho Chi Minh city and Song Tu Tay, in comparion with GPS solutions at Palawan [2] and Borneo from PCGIAP and APRGP [18], we identified no significant difference of velocities at STT1, CDA1 in East Vietnam Sea and KUCH, MIRI, KINA in NW Borneo. Maximum strain rates at the triangle T11, T12, T13 and T14 range from 2 to 7 nanostrain/year. This is contrary to the results of Simons et al. [2]. Our result indicates that there is no existence of an active subduction zone at North Borneo and the boundary of the Sunda block is shifted to the south of Borneo because there is a great change of velocities across the boundary. No existence of an active subduction zone at NW Borneo is justified by the absence of inverse earthquake focal mechanisms in this area. Shortening in the delta toe at NW Borneo is purely related to the upslope gravitational extension [30]. The difference of our solution and Simons et al. [2] may be due to 3 causes: 1) Sunda block is not completely rigid but small deformed. Local deformation in the East Vietnam Sea is identified thanks to denser GPS network in this study. The compression at NW Borneo recognized by Simons et al. (2007) is the result of the comparison between NW Borneo and the center of Sunda; 2) Our measurement is in post-seismic time after 2004 Sumatra-Andaman earthquake. The effect of Sumatra-Andaman earthquake is very important. Co-seismic jumps of 3-5 $\mathrm{mm}$ were detected at NW Borneo and East Vietnam Sea [17]. After the 2004 Sumatra earthquake, the post-seismic deformation has been very significant in the far-field; SST1 and NW Borneo have moved more than 3 times compared to the initial co-seismic displacement (Simons, personal communication, 2011); 3) NTUS, BAKO, KUNM and WUHN do not follow their ITRF-2005 motions after 2005 (Simons, personal communication, 2011). However, the two latest causes produce only small differences. Continuous GPS solution from 1999 to 2009 in YONG shows that slip rate has not changed before and after the 2004 Sumatra earthquake (figure 7). The distance from the epicenter of the 2004 Sumatra earthquake to YONG, STT1, PUER, KINA is equivalent to more than $1000 \mathrm{~km}$.

Combining our measurement with the velocity at PUER in Palawan, we identify a large extension in the triangle T14 in table 2. The velocity at PUER site is from Simons et al. (2007). However, this velocity was recorded 
before the Sumatra Andaman earthquake. To estimate the error produced from the combination of velocities determined after Sumatra-Andaman earthquake and velocities recorded before the earthquake, we calculate the strain rate with the velocities of TABA, BRUN, and PUER recorded before SumatraAndaman earthquake from [2]. The result is represented in table 4 . We note that the coordinate of T11, T12, and T13 in table 2 is quite different from to the coordinate of T11, $\mathrm{T} 12$, and T13 in table 3 . The compressive strain rate is not significantly different, but the extensive strain rate changes from 2 to 6 nanostrain/yr. The error 6 nano-strain/yr of extensive strain rate of $\mathrm{T} 11, \mathrm{~T} 12$, and $\mathrm{T} 13$ in table 4 is also larger than the error in table 2. This means the large extension in T14 is mainly from regional tectonics. This extension has to be studied in the future.

WMFZ is located in the area bounded by the rays STT1-DOHO and STT1-CDA1 (figure 1). The velocities of HUES and LANG are not considered due to symmetric properties of mesh size of deformation network. The result in the table 2 shows that DOHO, CDA1 and HOCM move to the east at the rate from $1.0 \pm 1.8$ $\mathrm{mm} / \mathrm{yr}$ to $6.3 \pm 1.9 \mathrm{~mm} / \mathrm{yr}$, to the north at the rate from $0.0 \pm 1.8 \mathrm{~mm} / \mathrm{yr}$ to $0.7 \pm 1.8 \mathrm{~mm} / \mathrm{yr}$. This indicates that WMFZ is left strike-slip fault with compressive component. Maximum left lateral slip rate of this fault zone is less than $2.5 \mathrm{~mm} / \mathrm{yr}$. Earthquake focal mechanisms in this fault zone are consistent with the left lateral displacement of this fault zone. The result in the table 4 shows that the principal strain rate at the triangle $\mathrm{T} 9$ is in order of several nano-strain/yr. The maximum shear strain rate is less than 6 nano-strain/yr. The directions of maximum and minimum principal strain rates are consistent with left lateral strike slip of WMFZ. The earthquake focal mechanisms in this area are compatible with the distribution of the direction of principal strain rates. The earthquakes occurring along this fault zone can not produce tsunamis because tsunami is related only to dipslip faults.
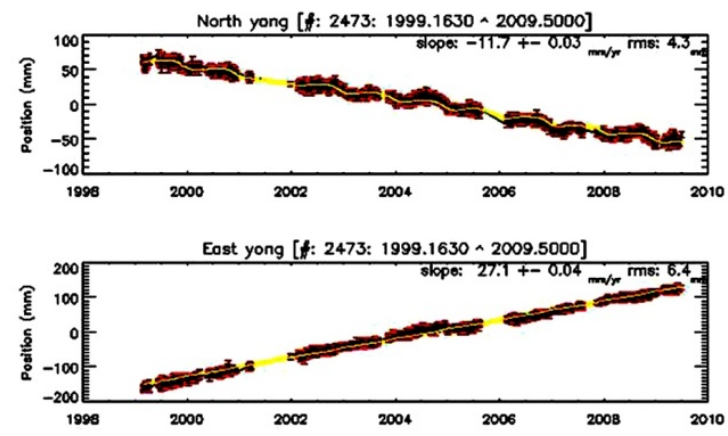

Fig. 7. Continuous GPS solution from 1999 to 2009 in YONG demonstrates that slip rate does not change before and after 2004 Sumatra earthquake (GPS solution from CMONOC projects). The distance between 2004 Sumatra earthquake epicenter and Yong is similar to the distance between this earthquake epicenter and STT1, PUER, KINA

Table 5. Strain rate calculated by the combination of GPS data measured in North Borneo before 2004 Sumatra earthquake from Simons et al. [2], Dawson et al. [25] and this study

\begin{tabular}{|c|c|c|c|c|c|c|c|c|c|c|}
\hline $\mathbf{N}$ & LON & LAT & SR1 & $\sigma R 1$ & SR2 & $\sigma R 2$ & D2 & ED2 & SSR & $\sigma S R$ \\
\hline $\mathrm{T} 1$ & 105,750 & 20,902 & 9.3 & 7.2 & -11.0 & 2.8 & -12 & 11 & 10.2 & 3.9 \\
\hline T2 & 106,950 & 23,480 & 5.4 & 1.3 & -6.7 & 2.3 & -26 & 6 & 6.1 & 1.3 \\
\hline T3 & 110,133 & 20,725 & 3.6 & 3.4 & -2.7 & 0.4 & -20 & 16 & 3.2 & 1.8 \\
\hline $\mathrm{T} 4$ & 113,147 & 20,930 & -1.7 & 0.2 & -3.7 & 0.3 & 120 & 5 & 1.0 & 0.2 \\
\hline T5 & 115,062 & 23,483 & 0.7 & 0.3 & -4.4 & 0.3 & -30 & 2 & 2.6 & 0.3 \\
\hline T6 & 108,902 & 18,172 & 7.2 & 3.4 & -8.8 & 5.1 & -9 & 11 & 8.0 & 3.1 \\
\hline T7 & 111,125 & 15,279 & 9.6 & 2.8 & -5.2 & 2.1 & -22 & 7 & 7.4 & 1.8 \\
\hline T8 & 114,446 & 16,330 & -0.4 & 0.9 & -10.0 & 2.3 & 114 & 7 & 4.8 & 1.3 \\
\hline T9 & 109,187 & 13,613 & 6.9 & 4.5 & -3.5 & 2.7 & 105 & 14 & 5.2 & 2.6 \\
\hline $\mathrm{T} 10$ & 108,516 & 10,716 & 1.8 & 2.2 & -15.0 & 6.4 & -20 & 12 & 8.4 & 3.4 \\
\hline T11 & 106,406 & 3,634 & 7.4 & -5.9 & -6.9 & 2.0 & 33 & 6 & 7.2 & 1.5 \\
\hline T12 & 110,199 & 4,852 & 6.7 & -4.1 & -2.7 & 3.0 & 31 & 11 & 4.7 & 1.8 \\
\hline T13 & 112,005 & 8,379 & 6.6 & -2.2 & -2.1 & 1.7 & 30 & 15 & 4.4 & 1.3 \\
\hline $\mathrm{T} 14$ & 116,070 & 8,833 & 17.7 & -2.5 & -2.4 & 1.6 & 18 & 8 & 10.1 & 2.1 \\
\hline
\end{tabular}


Duong \& Feigl [31] identified the maximum rate of dextral shear along the Red River fault being less than $0.3 \mu \mathrm{rad} /$ year. Feigl et al. [32] considered that the Red River fault did not slip faster than $2 \mathrm{~mm} / \mathrm{yr}$ between 1994 and 2001. Simons et al. [2] considered that this fault zone is the northern boundary of Sunda block. Michel et al. [3], Iwakuni et al. [5] showed no significant differential motion between the Sunda and South China blocks. Our result in the East Vietnam Sea also presents no significant variation of displacements between two blocks. However, through analysis of strain rate in the triangle T2, we obtain maximum principal strain rate and maximum shear strain rate in order of 10-8 (?)/year. This value is higher in comparison with that of other places in Sunda blocks. The distribution of the direction of maximum and minimum principal strain rates shows that it is consistent with right lateral strike-slip sense of the Red River fault zone.

\section{CONCLUSION}

Through four GPS campaigns in 2007, 2008, 2009 and 2010, basic characters of present-day tectonic movement on the East Vietnam Sea were identified with the eastsoutheastward movement in the north and the southeastward one in the south of the East Vietnam Sea. GPS stations in the north of East Vietnam Sea move eastwards at the slip rate of $30-39 \mathrm{~mm} / \mathrm{yr}$, southwards at $8-11 \mathrm{~mm} / \mathrm{yr}$. Stations move to the southeastat the rate of $\sim 22 \mathrm{~mm} / \mathrm{yr}$ and to the south at the velocities of $7-11 \mathrm{~mm} / \mathrm{yr}$. The deformation in the East Vietnam Sea is low with the principal strain rate from 2 nano-strain/year to 15 nanostrain/year. Thanks to higher GPS networks from this study in combination with other GPS solutions of different projects, we can make in evidence local deformation in the East Vietnam Sea. Strain field in continental shelf is in transitional regime, compatible with earthquake focal mechanisms and state of stress in this area, but in some areas, we can observe compressive regime like in $\mathrm{T} 4, \mathrm{~T} 8, \mathrm{~T} 11$. The deformation along the Red River basin is rather high with a maximum shear strain rate of 10 nano-strain/year, butit is rather low in the south of Vietnam - North Borneo with maximum shear strain rate of 2 nano-strain/year. In particular, this study makes in evidence a local extension at NW tip of Borneo, instead of an active subduction zone suggested by previous study. The result of this study suggests that there is no local source of tsunami located on the western margin of the East Vietnam Sea and North Borneo. Due to short time of investigation, the error of relative movement of WMFZ is larger than $1.8 \mathrm{~mm} /$ year. Maximum left lateral slip rate of this fault zone is less than $2.5 \mathrm{~mm} / \mathrm{yr}$.

Acknowledgments: We thank Dr. Beavan for helping Dr. Ngo Van Liem in the stage of BERNESE software, Dr. Le Huy Minh for supporting GPS data in Ho Chi Minh and Hue, Dr. Dawson for supporting GPS solutions of PCGIAP and APRGP. We are grateful to Prof. Kato for supporting GPS receiver at Lang station. We thank Jet Propulsion Laboratory for the license of QOCA. We express our thanks to Simons for fruitful comments. This work is a contribution of the project 03/2012 "Estimation of late Pleistocene and present tectonic gradient in the region of Ninh Thuan Nuclear Power Plant" and project TN3/T06: "Actual geodynamics in Western plateau for the estimation of geological hazards related to the dams and reservoirs".

\section{REFERENCES}

1. England, P., and Houseman, G., 1986. Finite strain calculations of continental deformation: 2. Comparison with the India-Asia collision zone. Journal of Geophysical Research: Solid Earth (19782012), 91(B3): 3664-3676.

2. Simons, W. J. F., Socquet, A., Vigny, C., Ambrosius, B. A. C., Haji Abu, S., Promthong, C., Subarya, C., Sarsito, D. A., Matheussen, S., Morgan, P., and Spakman, $W ., 2007$. A decade of GPS in Southeast Asia: Resolving Sundaland motion and boundaries. Journal of Geophysical Research: Solid Earth (1978-2012), 112(B6).

3. Michel, G. W., Yu, Y. Q., Zhu, S. Y., Reigber, C., Becker, M., Reinhart, E., Simons, W., Ambrosius, B., Vigny, C., Chamot-Rooke, N., Pichon, X. L., Morgan, 
P., and Matheussen, S., 2001. Crustal motion and block behaviour in SE-Asia from GPS measurements. Earth and Planetary Science Letters, 187(3): 239-244.

4. Hall, R., and Morley, C. K., 2004. Sundaland basins. Continent-Ocean Interactions Within East Asian Marginal Seas, 55-85.

5. Iwakuni, M., Kato, T., Takiguchi, H., Nakaegawa, T., and Satomura, M., 2004. Crustal deformation in Thailand and tectonics of Indochina peninsula as seen from GPS observations. Geophysical research letters, 31(11).

6. Leloup, P. H., Lacassin, R., Tapponnier, P., Schärer, U., Zhong, D., Liu, X., Zhang, L., Ji, S., and Trinh, P. T., 1995. The Ailao Shan-Red River shear zone (Yunnan, China), Tertiary transform boundary of Indochina. Tectonophysics, 251(1): 3-84.

7. Leloup, P. H., Arnaud, N., Lacassin, R., Kienast, J. R., Harrison, T. M., Trong, T. T., Replumaz, A., and Tapponnier, P., 2001. New constraints on the structure, thermochronology, and timing of the Ailao Shan-Red River shear zone, SE Asia. Journal of Geophysical Research: Solid Earth (1978-2012), 106(B4), 6683-6732.

8. Tapponnier, P., Peltzer, G., Le Dain, A. Y., Armijo, R., and Cobbold, P., 1982. Propagating extrusion tectonics in Asia: new insights from simple experiments with plasticine. Geology, 10(12): 611-616.

9. Allen, C. R., Gillespie, A. R., Yuan, H., Sieh, K. E., Buchun, Z., and Chengnan, Z., 1984. Red River and associated faults, Yunnan Province, China: Quaternary geology, slip rates, and seismic hazard. Geological Society of America Bulletin, 95(6): 686-700.

10. Phan Trong Trinh, Ngo Van Liem, Nguyen Van Huong, Hoang Quang Vinh, Bui Van Thom, Bui Thi Thao, Mai Thanh Tan, Nguyen Hoang, 2012. Late Quaternary tectonics and seismotectonics along the Red River fault zone, North Vietnam. EarthScience Reviews, 114(3): 224-235.

11. Trinh, P. T., Vinh, H. Q., Van Huong, N., and Van Liem, N., 2013. Active fault segmentation and seismic hazard in HoaBinh reservoir, Vietnam. Central European Journal of Geosciences, 5(2): 223-235.

12. Shen, Z. K., Lü, J., Wang, M., and Bürgmann, R., 2005. Contemporary crustal deformation around the southeast borderland of the Tibetan Plateau. Journal of Geophysical Research: Solid Earth (1978-2012), 110(B11).

13. Rangin, C., Le Pichon, X., Mazzotti, S., Pubellier, M., Chamot-Rooke, N., Aurelio, M., Walpersdorf, A., and Quebral, R., 1999. Plate convergence measured by GPS across the Sundaland/Philippine Sea plate deformed boundary: the Philippines and eastern Indonesia. Geophysical Journal International, 139(2): 296-316.

14. King, $\quad R . \quad W ., \quad$ and Bock, Y., 2003. Documentation for GAMIT GPS analysis software, release 10.1 MIT. Cambridge.

15. Dong, D., Herring, T. A., and King, R. W., 1998. Estimating regional deformation from a combination of space and terrestrial geodetic data. Journal of Geodesy, 72(4): 200-214.

16. Feigl, K. L., Agnew, D. C., Bock, Y., Dong, D., Donnellan, A., Hager, B. H., Herring, T. A., Jackson, D. D., Jordan, T. H., King, R. W., Larsen, S., Larson, K. M., Murray, M. H., Shen, Z., and Webb, F. H., 1993. Space geodetic measurement of crustal deformation in central and southern California, 1984-1992. Journal of Geophysical Research: Solid Earth (19782012), 98(B12): 21677-21712.

17. Vigny, C., Simons, W. J., Abu, S., Bamphenyu, R., Satirapod, C., Choosakul, N., Subarya, C., Socquet, A., Omar, K., Abidin, H. Z., and Ambrosius, B. A. C., 2005. Insight into the 2004 SumatraAndaman earthquake from GPS measurements in southeast Asia. Nature, 436(7048): 201-206.

18. Hu, G., and Dawson, J., 2010. The Asia Pacific Regional Geodetic Project (APRGP) GPS solution (1997-2008), XXIV FIG, (www.icsm.gov.au/icsm/FIG/CongressPape r4113.pdf). 
19. Hu, X., Wang, Q., Ma, Q., and Du, X., 2007. Research and application of regional no-net-rotation reference frame. J. Geodesy \& Geodynamics, (in Chinese with English abstract) 27(2): 52-60.

20. Lê Huy Minh, Frédéric Masson, Alain Bourdillon, Patrick Lassudrie Duchesne, Rolland Fleury, Jyr-ching Hu, Vũ Tuấn Hùng, Lê Trường Thanh, Nguyễn Chiến Thắng, Nguyễn Hà Thành, 2014. Chuyển động hiện đại vỏ trái đất theo số liệu GPS liên tục tại Việt Nam và khu vực Đông Nam Á. Tạp chí Các Khoa học về Trái đất, 36(1): 1-13.

21. Lê Huy Minh, Kurt Feigl, Frédéric Masson, Duong Chi Công, Alain Bourdillon, Patrick Lassudrie Duchesne, Nguyễn Chiến Thắng, Nguyễn Hà Thành, Trần Ngọc Nam, Hoàng Thái Lan, 2010. Dịch chuyển vỏ Trái Đất theo số liệu GPS liên tục tại Việt Nam và khu vực Đông Nam Á. Tạp chí Các Khoa học vềं Trái đất, 32(3): 249-260.

22. Beavan, J., Tregoning, P., Bevis, M., Kato, T., and Meertens, C., 2002. Motion and rigidity of the Pacific Plate and implications for plate boundary deformation. Journal of Geophysical Research: Solid Earth (1978-2012), 107(B10), ETG-19.

23. Bock, Y., Prawirodirdjo, L., Genrich, J. F., Stevens, C. W., McCaffrey, R., Subarya, C., Puntodewo, S. S. O., and Calais, E., 2003. Crustal motion in Indonesia from global positioning system measurements. Journal of Geophysical Research: Solid Earth (1978-2012), 108(B8).

24. Chamot-Rooke, N., and Le Pichon, X., 1999. GPS determined eastward Sundaland motion with respect to Eurasia confirmed by earthquakes slip vectors at Sunda and Philippine trenches. Earth and Planetary Science Letters, 173(4): 439-455.

25. Dawson, J., Luton, G., and Govind, R., 2004. Permanent Committee for GIS Infrastructure for Asia and the Pacific, 1997,
1998， 1999, 2000, 2001， 2002 GPS Campaign Analysis. PCGIAP Report. 566p.

26. Galgana, G., Hamburger, M., McCaffrey, R., Corpuz, E., and Chen, Q., 2007. Analysis of crustal deformation in Luzon, Philippines using geodetic observations and earthquake focal mechanisms. Tectonophysics, 432(1): 63-87.

27. Gan, W., Zhang, P., Shen, Z. K., Niu, Z., Wang, M., Wan, Y., Zhou, D., and Cheng, $J ., 2007$. Present-day crustal motion within the Tibetan Plateau inferred from GPS measurements. Journal of Geophysical Research: Solid Earth (1978-2012), 112(B8).

28. Zhang, P. Z., Shen, Z., Wang, M., Gan, W. Bürgmann, R., Molnar, P., Wang, Q., Niu, $Z$., Sun, J., $W u$, J., Hanrong, S., and Xinzhao, Y., 2004. Continuous deformation of the Tibetan Plateau from global positioning system data. Geology, 32(9): 809-812.

29. Kashani, I., Wielgosz, P., and GrejnerBrzezinska, D. A., 2004. On the reliability of the VCV Matrix: A case study based on GAMIT and Bernese GPS Software. GPS Solutions, 8(4): 193-199.

30. King, R. C., Backé, G., Morley, C. K., Hillis, R. R., and Tingay, M. R., 2010. Balancing deformation in NW Borneo: quantifying plate-scale vs. gravitational tectonics in a delta and deepwater foldthrust belt system. Marine and Petroleum Geology, 27(1): 238-246.

31. Cong, D. C., and Feigl, K. L., 1999. Geodetic measurement of horizontal strain across the Red River fault near Thac Ba, Vietnam, 1963-1994. Journal of Geodesy, 73(6): 298-310.

32. Feigl, K. L., Cong, D. C., Becker, M., To, T. D., Neumann, K., and Xuyen, N. Q., 2003. Insignificant horizontal strain across the Red River Fault near Thac Ba, Vietnam from GPS measurements 1994-2000. In EGS-AGUEUG Joint Assembly (Vol. 1, p. 4707). 


\title{
BIẾN DẠNG HIỆN ĐẠI BIỂN ĐÔNG VIẸTT NAM VÀ LÂN CẬN
}

\section{Phan Trọng Trịnh, Ngô Văn Liêm, Trần Đình Tô, Nguyễn Văn Hướng, Vy Quốc Hải, Bùi Văn Thơm, Trần Văn Phong, Hoàng Quang Vinh, Nguyễn Quang Xuyên, Nguyễn Viết Thuận, Nguyễn Đăng Túc, Đinh Văn Thuận, Nguyễn Trọng Tấn, Bùi Thị Thảo, Nguyễn Việt Tiến, Lê Minh Tùng, Trần Quốc Hùng}

\author{
Viện Địa chất-Viện Hàn lâm Khoa học và Công nghệ Việt Nam
}

TÓM TĂT: Bài viết trình bày tốc độ chuyển động kiến tạo hiện đại và tốc độ biến dạng trên Biển Đông Việt Nam và lân cận tù các đợt đo GPS tù 2007 tới 2010. Việc xác định tốc độ chuyển dịch tuyệt đối trong hệ thống ITRF05 cho thấy bắc Việt Nam chuyển dịch về phía đông với tốc độ dao động trong khoảng 30 - $39 \mathrm{~mm} /$ năm, chuyển dịch về phía nam với tốc độ trong khoảng 8 $11 \mathrm{~mm} / \mathrm{năm}$. Đảo Song Tủ Tây chuyển dịch về phía đông với tốc độ xấp xỉ $24 \mathrm{~mm} / \mathrm{năm}$ và chuyển dịch về phía nam với tốc độ $9 \mathrm{~mm} / \mathrm{năm}$. Các điểm đo GPS ở nam Biển Đông chuyển dịch với tốc độ $22 \mathrm{~mm} / \mathrm{năm}$ và dịch chuyển về phía nam với tốc độ $7-11 \mathrm{~mm} / \mathrm{năm}$. Kết quả tính toán cho thấy chuyển dịch tương đối của đới đứt gãy suờn đông Việt Nam chuyển dịch như đới đưt gãy trươt bằng trái với tốc độ nhỏ hơn $4 \mathrm{~mm} /$ năm. Tại Tây Nguyên, kết quả ban đầu chu kỳ $2012-2013$ cho thấy toàn vùng Tây Nguyên chuyển dịch về phía đông với tốc độ giao động tù $21,5 \mathrm{~mm} /$ năm tới $24,7 \mathrm{~mm} / \mathrm{năm}$. Tốc độ chuyển dịch về phía nam giao động tù $10,5 \mathrm{~mm} / \mathrm{năm}$ tới $14,6 \mathrm{~mm} / \mathrm{năm}$. Kết hơp với các số đo GPS tù các mạng luơoi khác, chúng tôi đã xác định được tốc độ biến dạng hay gradient kiến tạo cho toàn khu vực Biển Đông và lân cận. Tốc độ biến dạng chính thay đổi tù̀ 15 nanno biến dạng/năm tới 9 nano biến dạng/năm. Tốc độ biến dạng truợt dọc đới đứt gãy Sông Hồng trong khoảng 10 nanno biến dạng/năm. Biển Đông Việt Nam có thể xem là một phần của mảng Sunda.

Tù khóa: Chuyển động hiện đại, gradient kiến tạo, tốc độ chuyển dịch, đới hút chìm, tách giãn, tốc độ biến dạng chính, tốc độ trự̂t cực đại, Tây Nguyên. 